Akdeniz Kadın Çalışmaları ve

Toplumsal Cinsiyet Dergisi

http://dergipark.gov.tr/ktc

Sayı III (2) 233-249

Araştırma Makalesi

\title{
Duygu Asena'nın “Kadının Adı Yok” Romanı Üzerinde Bir İnceleme An Analysis of Duygu Asena's Novel "Woman Has No Name"
}

\section{Zeliha Kapukaya *}

Öz: Kadının Adı Yok Romanı, Türk Toplumunda kadının bireysel ve toplumsal hayatta karşılaştı̆ğ sorunları ele almaktadır. Türkiye'de feminizmin basın dünyasında ve popüler kültürde yaygınlaşmasında etkisi olan isimlerden Duygu Asena, eserinde kadın meselesini daha çok feminist hareketin kullandığı çerçevede işlemektedir. Roman, Türkiye'de 70'li yıllardan itibaren gündeme gelen feminizm hareketinin etkisiyle eşitlik, cinsellik, görünürlük ve bütünüyle özgürlük gibi somutlaşmış kavramların içinde kadının sesini geniş kitlelere duyurmayı başarmıştır. Eserin edebî değerinden çok kahramanının özgürlükçü rolü dikkat çekmiş; kitapta anlatılan içeriğin fazlasıyla gerçekliği, verdiği mesajların geniş toplumsal kitlelere net bir şekilde ulaşıp karşı1ık bulması kitabın başarısı olarak görülmüştür. Bu makalenin amacı edebiyat çevrelerince edebî değeri olmadığı gerekçesiyle ele alınmamış, önyargı ile yaklaşılmış Kadının Adı Yok romanını incelemektedir. Yazılış amacına fazlasıyla ulaşmış olan roman; kurgu, dil, üslup vb. bakımından olmasa da tematik açıdan kadın meselesini etraflıca ve cesur bir yaklaşımla ele almaktadır. Bu nedenle içerik yönüyle öncü bir eserdir. Toplumsal bellekte böylesine iz bırakmış ve dönemin sosyo-kültürel şartlarını gerçekçi bir şekilde yansıtmış olan Kadının Adı Yok Romanı Türkiye'de kadın hareketini anlamak açısından değer arz etmektedir.

Anahtar Kelimeler: Duygu Asena, Türkiye'de Kadın, Feminist Edebiyat.

Abstract: The novel Kadının Ad1 Yok (The Woman Has No Name)deals with the problems faced by women in individual and social life in Turkish society. In the novel Kadının Adı Yok (The Woman Has No Name), the problems faced by women in Turkish society in their private and social lives are discussed. Turkey feminism in the world press and the spread of the names that have an impact on popular culture Duygu Asena, the novel is in the process of women's issues in the framework of the feminist movement more use. Duygu Asena -who had a great impact on the spread of feminism through press and popular culture in Turkey- discussed the issues of women as it is discussed in the feminist movement framework. The Novel, starting from 70 years in Turkey by the action of equality on the agenda of feminism, sexuality, the voice of the woman as embodied in the concept of freedom has been able to announce the visibility and wider audiences. With the influence of feminist movement that started by 1970s in Turkey; the notions of equality, sexuality, visibility and total freedom are used as a tool to convey the voice of women to large masses in this novel. The libertarian role of the protagonist of the work rather than its literary value was

\footnotetext{
* Öğr. Gör. Dr., Balıkesir Üniversitesi, Türk Dili Bölümü, zelihakapukaya10@ hotmail.com,
} 
found to be remarkable. In spite of this, the truly realistic nature of the content and the fact that its message reaches out to wide social masses in a clear way have been seen as the success of the novel. The aim of this article is to examine the novel called Kadının Adl Yok, which is not discussed by literary circles on the grounds that it has no literary value. Although not in terms of design, language, style etc., the novel discusses women's issues thematically in a comprehensive and courageous way. Therefore, it is considered to be a pioneer contentwise. In the novel Kadının Adı Yok socio-cultural conditions of the period are reflected realisticallyby leaving many traces in the memories of the society and the novel is of value in understanding the women's movement in Turkey.

Keywords: Duygu Asena, Women in Turkey, Feminist Literature

\section{Summary}

One of the most significant representatives of feminism in popular culture and the world press in Turkey is Duygu Asena. Her first work on feminist literature is Kadının Adı Yok. The novel Kadının Adı Yok, published in 1987, deals with the problems faced by women in their individual and social lives in Turkish society. In her novel, Asena deals with women's issues within the framework of the feminist movement. The work that is integrated with the name of Duygu Asena; brought the women's issue to a wide social platform and introduced the Turkish reader an assertive novelist. In the novel, how even educated and professional women have problems in claiming their rights and freedom, how women who defend themselves against the society and established values are excluded by the system are clearly explained. The work glorifies love, telling women how to live an honorable and equal life and advises them to live as they believe and not feel guilty about it. The novel is almost a women's manifesto. It is emphasized in the novel that the socio-economic and psychological strength of women is the only gateway to their freedom. It is a serious response to the system that advises women to live within acceptable limits and to serve their home and husband. The main problem in the novel is that the existence of women is in conflict with social norms, they are prevented, their personality, sexual and social identity are not respected, they are totally objectified, devalued and ignored by men. In this problem, women experience all types of conflict. ( While dealing with these identity problems as an individual, women face all types of dilemmas.)The most important conflict of these women is related to their social roles assigned by the society. In a sense, the novel is a parody of institutions such as marriage, work and love, with the forms imposed by the system. In the novel, the journey of the woman who fights with herself and the social and cultural systems surrounding her, the journey of becoming an individual and emancipation, the problems she encountered in this journey, the methods to overcome them and how to fight are explained. The theme of love is handled in the novel within the framework of the theme of freedom. The phenomenon of infidelity encountered 
in male-female relationships is elaborated in the novel from a female perspective. The message given to the reader on this issue is the virtue of standing behind and honesty, even if it is a huge mistake made in female-male relationships. Issues such as the mistake of looking at women's own body and sexuality within social codes, growing up as a girl in a patriarchal family, youth sexuality and the problems it caused, the right of women to education, and the wage inequality women face in worki life are also covered in the novel. The novel Kadının Adı Yok left a mark in the social memory and reflected the socio-cultural conditions of the period in a realistic way. Therefore, it is a pioneering work and the content of the work is of value in terms of understanding the women's movement in Turkey.

\section{Giriș}

1980 sonrası Türk düşünce dünyasında kadının toplumdaki konumunu ve problemlerini; makaleleri, röportajları, roman ve tiyatro senaryolarıyla gündeme getiren Asena, gazeteciliği ve diğer faaliyetleri ile kadın meselesinin popüler kültür dünyasında belirginlik kazanmasında önemli bir rol üstlenmiştir. Eser, bilhassa erkek egemen bir toplumun belirlediği sınırlar içinde kadın olmayı tartışan yönleriyle adeta kadının varoluş mücadelesinin bir manifestosudur. Asena'nın ilk romanı olan Kadının Adı Yok, yazarın biyografisinden de izler taşımaktadır Özellikle basın ve edebiyat dünyasında tabu sayılan konuları şartları zorlayarak işlemesi Türk Romanı için bir ilktir.

Eser yayımlandığı tarihten itibaren başta sanatsal değeri, meseleleri ele alış tarzı, üslubu vb. bakımlardan çeşitli çevrelerce tartışmaların merkezinde olmuştur. 1987'de çıkan kitap bir yıl içinde 40 baskı yapmış, 520 bin satışla adeta bir rekor kırmıştır.(DAS, 157) Ayrıca yasaklanıp toplatılması kitaba olan ilgiyi artırmış daha sonraki yıllarda kitap rekor kırmaya devam etmiştir. Edebî çevreler, edebî değerinin olmadığı gerekçesiyle kitabı pek dikkate almamıştır. Bu denli dikkat çekmiş ve rekor kırmış bir kitabın görmezden gelinmesi Türk Edebiyatında feminizm hareketinin anlaşılması açısından bir eksikliktir. Tüm bu sebeplerden dolayı bu çalışma böylesine çok okunmuş ve kadının bireysel ve toplumsal hayatta karşılaştığı sorunlara dikkat çekmesi suretiyle dikkat çekmiş eserin değerinin ve öneminin ortaya konulmasını amaçlamaktadır.

\section{Kisaca Duygu Asena}

Duygu Asena 19 Nisan 1946'da İstanbul'da doğmuştur. İstanbul Üniversitesi Edebiyat Fakültesi Pedagoji Bölümü mezunudur. Haseki Hastanesi Çocuk Kliniği ve İstanbul Üniversitesi Çocuklarevi'nde iki yıl pedagog olarak çalışmıştır. 1972 yılında Hürriyet Gazetesinde gazeteciliğe başlamış, gazetenin “Kelebek” ekinde “Şirin” imzasıyla köşe yazıları yazmıştır. 1978’te Gelişim Yayınlarında Genel Yayın Yönetmeni olan Asena, sonraki senelerde Kadınca ile beraber On yedi, Ev Kadını, Bella Bayan, Kim, First, Negatif gibi dergileri yönetmiştir. Duygu Asena'nın "feminist” 
kimliği Kadınca dergisini yönettiği dönemde belirginleşmiştir. Kadınca Dergisinin yüksek tiraj1 sayesinde o güne kadar Türk basının ilgi göstermediği feminizm dikkate alınmaya, sorgulanmaya başlanmıştır. 80 sonrası ivme kazanan kadın hareketinin doğrudan içinde olmasa da feminist gündemi basın ve yazın dünyasına taşıyarak bu hareketi desteklemiştir. Söz, Sabah, Güneş, Yarın, Milliyet, Cumhuriyet ve Vatan gazetelerinde köşe yazarlığı, yöneticilik ve röportaj yazarlı̆̆ı yapmıştır. Asena, 30 Temmuz 2006 tarihinde hayatını kaybetmiştir. Eserleri: Kadının Adı Yok, Aslında Aşk Da Yok, Kahramanlar Hep Erkek, Değişen Bir Şey Yok, Aynada Aşk Vardı, Aslında Özgürsün, Aşk Gidiyorum Demez, Paramparça...(Yıldız, 2007, 11-12)

Duygu Asena, daha çok kadın sorunlarını Kelebek (1972-74), Ayrıntılı Haber (1975), Kadınca (1978-88) dergilerinde yayımlamıştır. Bu yazılarıyla feminist kimliği öne çıkmıştır. İki yılda kırk baskı ile satış rekoru kıran, daha sonra elli üç baskıya ulaşan Kadının Adı Yok kitabı büyük üne kavuşmuştur. 40. Baskısının satışları sürerken "Başbakanlık Küçükleri Muzır Neşriyattan Koruma Kurulu” tarafından “muzır” bulunarak satışı yasaklanmıştır. Bunun üzerine Asena'nın açtığı davada kitap aklanmıştır. Yeni baskıları yayımlanarak, 53 baskıya ulaşan kitap; Almanya, Hollanda ve Yunanistan'da bu ülkelerin dillerine çevrilmiş, Yunanistan'da "best seller" olmuştur. Kadının Adı Yok Boğaziçi Üniversitesince de "Yılın Kitabı”" seçilmiştir.(1988) (Işık, $2013 ; 40-41)$.

\section{Türkiye'de Feminist Edebiyat ve Duygu Asena}

Türkiye'de tek tek örnekleri dışında kronolojik bir süreç içinde “feminist edebiyat”tan başlı başına söz etmek mümkün değildir. 1950 öncesi Suat Derviş, Kerime Nadir, Halide Edip gibi yazarların roman ve hikâyelerinde kadın konusunu "kadın kahramanların yazgılarına boyun eğdiği, resmî ideolojiyi destekleyen, cinsel erdemin her şeyden önde tutulduğu" yolunda söylemler çerçevesinde yazmışlardır. Türkiye'de siyasî arenada kadın hareketinin tam manasıyla karşılık bulamaması kadının edebî metinlerde ideolojik destekli veya oldukça saklı bir eleştiri üslubunda yer alması sonucunu doğurmuştur. 70'li yılardan sonra bu suskunluk son bulmuş; Nezihe Meriç, Leyla Erbil ve Adalet Ağaoğlu ile kadın meselesi son derece gerçekçi bir şekilde ele alınmıştır. Pınar Kür, Sevgi Soysal, Tomris Uyar, Ayla Kutlu ve Füruzan gibi kadın yazarların toplumdaki cinsiyet rollerini sorgulamaları ve hesaplaşmaları Türkiye'de feminist edebiyata yeni bir ivme kazandırmıştır. Ayrıca kadın hareketinin siyasi arenaya taşınması dönemin sol ideolojisinde şekillenen bir başkaldırının uzantısı olarak görülebilir.(DAS, 57-58)

1980’li yıllarda ise kadın hareketi Batı'dan on yıl sonra Türkiye'ye gelmiş, bu yıllar kadınların kimlik ve bedenlerini öne çıkararak haklarını aradıkları hareketli bir dönem olarak görülmüştür. İşte bu dönemde Duygu Asena’nın Kadının Adı Yok Kitabı dönemin Medeni Kanun 
reformuna, Ceza Kanununun kadın karşıtı söylemine, toplumsal tabuların sorgulanmasına yönelik önemli bir karş1lık cevap niteliğindedir. Müge İplikçi’nin ifadeleriyle:

Kadının Adı Yok: Geçmişin izini sürdüğümüzde karşımıza çıkan romantik aşkın varlığı ile bütünleşen yapı yerle bir edilmiş; arayışını iffet ve hicap duygusuyla sürdüren kahramanların umduğu mutlu evliliklerin bir hayal olduğu bir kez daha ortaya çıkarımıştı....Kitap 80'li yılların tam içinden süzüldü ve başka bir şeyi başardı. Popüler oldu, hemen her kesim kadın tarafından sahip çıkıldı. Çok eleştirildi, kimi kez baş tacı edildi. Her iki durumda da üzerinde çok konuşuldu. Yapıtın açtığı alanlar içerisindeki "gerçekçilik" olgusu kendi kendine tanıklık etmesi ve içeriğin sipsivri bir dille veriliyor olması, dönemin devletçe desteklenen mıymıntı, papatya sembollü fantezi feminizmine, kısaca demokrasi adına sözde çağ atlayacak ve Japon mucizesi yaratacak devlet politikasına kuşanmış Türkiye’ye verilmiş umulmadık bir cevaptı... (DAS, 59).

\section{Kadının Adı Yok}

Kadın ile ilgili hemen hemen bütün konuları çeşitli arenalarda değinen Asena; roman ve diğer yazın faaliyetleriyle toplumla iletişim kurmaya çalışmış bunun bir sonucu olarak ilk romanı Kadının Adı Yok (1987) yayımlanmıştır. Asena, Kadınca Dergisinin başarısının da büyük katkısıyla kadın hakları konusunda yarattığı etkiyi romanı ile farklı bir düzleme taşımıştır. $\mathrm{Bu}$ nedenle Kadınca dergisini ve Kadının $A d l$ Yok Romanını toplumun yaşadığı o süreç içinde değerlendirmek gerekir. Nilüfer Göle Romanı 1980'li yılların sosyal ikliminin bir başarısı olarak görmüş, Şirin Tekeli de yalnızca bir kadının hikâyesi değil, kadınlar için minimum kadın bilinci düzeyinde buluşma çağrısı olarak değerlendirmiştir (Öztürkmen 2000: 280-281).

Asena, romanında çocukluktan başlayarak kadınlığın bütün dönemlerinin hikâyesini anlatır. Kayda değer bir tanıtımı yapılmamasına rağmen yayımlandıktan birkaç ay sonra satış rekorları kıran eseri hakkında Asena şunları söyler:

Benim kitabımda bugüne kadar kimsenin önem vermediği ya da çok basit gördügü mesela bir kadının hayatındaki küçücük bir fizyolojik olayın bile onun ruhsal durumunda ne kadar önemli olduğu ve her an kadının ne kadar yalnız olduğuna değindim” (Asena, 26.09.2010).

Romanın başlığının da işaret ettiği gibi kadınların toplumda adı olmayan, adı olmadığı için de nesneleştirilen konumu tartışılmaktadır. Zira kadın ya birinin kızı veya kız kardeşi veyahut da karısıdır. Çalışmadığı, ev dışında toplumsal üretim hayatında yetersiz olduğu ve temsil edilmediği için pasif kalmakta kimliksizleştirilmektedir.

Bir röportajında, romanın edebî yönü ile ilgili olarak gelen eleştirilere kitabının bir edebiyat eseri ve kendisinin de bir edebiyatçı olma iddiasında olmadığını vurgulayarak cevap vermiştir. Yine aynı röportajında, kadının kendi dünyasına kendi gözüyle bakmasını sağlamayı ve kadının 
ezilmişliği, haklarına kavuşamaması konusundaki hassasiyetini yansıtmayı amaç edindiğini, kendisi için hayatın anlamının aşk olduğunu ve aşkın tedavi edici yönünün olduğunu belirtmiştir. Asena'nın sıraladığı düşünceler roman kahramanlarının kişiliğinde de görülür. Roman kahramanlarının yaşama sevincine dayanarak cinsiyetçiliğe, şiddete, kimliğine saygı duyulması yolunda verdiği mücadele ve bu mücadelenin yer yer aşka sığınarak karşı cinsle verilmesi onun bu anlayışını ortaya koymaktadır (Asena, 2010).

Kurgu, şahıs kadrosu, olaylar, dil ve üslup özellikleri açısından zayıf yönleri olan eserin asıl önemli tarafı güncelliğini devam ettiren tema ve konularıdır. Bu yönleriyle dönemi açısından öncü bir eserdir. Zaten amaç Türk toplumunda kadının, hayatının her döneminde karşılaştığ1 sorunları basit bir dil ve üslupla anlatmak, mesaj vermektir. Yazar, eğitimli, modern ve geleneksel değerlerin bir arada yaşandığı bir kültürde orta sınıf bir Türk kadınının karşılaştığı veya muhtemelen karşılaşacağı problemleri roman kahramanının hayatı üzerinden bir dizi halinde sıralamıştır. Asıl vaka kadının kozasından çıkarak özgürleşmesidir. Bu yolculukta yaşadığı olaylar kahramanının biyografisini tamamlayan durum ve yaşantılardır.

Romandaki temel problem, kadının varoluşunun toplumsal normlarla çatışması, engellenmesi, kişiliğine, cinsel ve toplumsal kimliğine saygı duyulmaması, bütünüyle kadının erkek karşısında nesneleştirilip değersizleştirilmesi ve yok sayılmasıdır. Bu problem içinde kadın bütün çatışma türlerini yaşamaktadır. En büyük çatışması kendisine biçilen rolle yani bir birey olarak toplumla çatışmasıdır.

Roman bir anlamda sistemin dayattığı şekilleriyle evlilik, iş ve aşk gibi kurumların bir parodisini yapmaktadır Roman kahramanı kendisini hapseden durumlara karşı bir anti oluş tavrı benimsemektedir. Roman sistemin ürettiği klişelerin, ataerkil aile yaşantısının, evliliğin, aşkın, iş hayatının ve bütünüyle modernitenin krizine yönelik bir parodidir. Krizi aşacak şey ise yaratıcı eylemdir. Roman kahramanının sorunlarını tespit edip bunları aşmak için çıktığı yol, yani özgürleşmesi en büyük yaratıcı eylemidir.

\section{İçerik ve Başlıca Karakterler}

Roman kahramanı kendini hatırlamaya başladığı 5-6 yaşlarından orta yetişkin bir kadın oluncaya kadar kendi perspektifinden kadınlığını bireysel ve toplumsal düzlemde yaşadıklarını anlatmaktadır. Romanın ismine paralel olarak anlatıcı kahramanın adı belirtilmemiştir. Kahraman, orta halli kent kökenli bir ailede dünyaya gelmiştir. Dünyaya geldiği aile ve toplum gelenek ile modernite arasında kalmış, geleneklerin erkeğin konumunu güçlendirdiği bir sosyal kurallar dizgesi içinde davranış kalıpları sergilemektedir. Kısıtlayıcı, erkek ve kız çocuk ayrımının derinlemesine yaşandığı bu sosyal çevrede kız çocukları sürekli erkek çocuklarından 
soyutlanmakta ve en masum oyunları bile sonu "karşıt cins ilişkisi" bakış açısı ile yorumlanabilmektedir. Anne ise susmaya mahkûm edilmiş tipik, ezilmiş bir Türk kadınıdır. Babanın güçlü hükümranlığı roman kahramanının erken yaşlardan başlayarak güçlü olmanın yollarını aramaya itmiştir. Gücün özgürlük demek olduğunu, özgürlüğün ise "cesaret ve ekonomik yeterlilik” ile mümkün olacağını kavramıştır.

Romanın bütününde hayatını sıfırlamayı başarabilmiş (!) kahramanın kız çocuk olmayı, eğitimi, evliliği, aşkı, çocuk sahibi olmayı, özgürlügü sorgulanmaktadır. Bu sorgulama ve örneklemelerde (aslında herhangi bir kadın olan) roman kahramanının hayatı merkeze alınmış, ailesi ve çevresinde gördükleri ile Türk kadının yaşadığı muhtemel problemler ve çözüm yolları okuyucunun dikkatine sunmuştur.

Lise döneminde gençlerin kadın-erkek ilişkilerinde yaşadığı sorunlar romanın ilk bölümlerinde geniş yer tutar. $\mathrm{Bu}$ sorunların başında ergen cinselliğinde karşılaşılan problemler bulunmaktadır. Bilgisizlikten, cinsellik eğitiminin eksikliğinden kaynaklanan durumların bir neticesi olarak ailesi ve erkek arkadaşı tarafından mağdur edilmiş kızların hikâyelerine yer verilmiştir. Romanın bu kısımlarında altı çizilen olgulardan en önemlisi kadın cinsel özgürlüğü ve kürtaj meselesidir.

Roman kahramanının babasına rağmen üniversiteye girmesi, okulunu bitirmesi, çalışma hayatına atılacak bir diplomaya sahip olması kendi hayatı adına atılmış ilk ve çok önemli bir adımdır. Saklaya saklaya girilen üniversite sınavı, babaya karşı başarıyla alınan üniversite diploması kadının bilhassa yükseköğretim hakkının dönemi için bir sorun olduğuna işaret eder. Bütün bu sancılı süreçlerin sonunda kadını özgürleştirecek iş hayatına girişi ve tüm eşitsizliklere karşı ekonomik özgürlüğünü kazanması zorlu süreçlerin sonunda kazandığı bir zaferdir.

Evliliğin ailenin baskısından kurtularak daha özgür bir hayata atılmanın bir yolu olarak görülmesinin yanlışlıkları roman kahramanının başından geçen evlilik hadisesi ve sonradan yaşanan olaylar üzerinden verilmiştir. Zira Türk toplumunda ekonomik ve sosyal olarak özgürlüğü olmayan bir genç kız için evlenmek, çoğu zaman saygınlık, statü ve (göreceli de olsa) özgürlüğün kazanılacağı bir olgudur. Roman kahramanı yaşadığı birkaç flörtün sonunda Gürkan (Ci-Ci) adında biriyle ilk evliliğini gerçekleştirmiştir. Oldukça iyi başlayan, sınırları belli ve rutinleşen günlük döngüler evliliğin çatırdamasına neden olmuştur. Bu rutini kırmak ve özgüven kazanmak için zamanla oldukça başarılı bir iş hayatına, yeni bir çevre ve arkadaşlıklara sahip olmuştur. Gürkan'ın kendisini evlilik müessesesinde bir vitrin olarak gördüğünü, samimiyetsizliğini anladıktan sonra ondan uzaklaşır. Toplantılara, iş yemeklerine bir aksesuar gibi götürülen roman kahramanı, içinde bulunduğu sahte dünyanın farkına varır. Yaşadığı boşluğu iş hayatına atılarak 
aşmak ister. Eşinin sekreteriyle kendisini aldatması zaten pek de mutlu bir evliliği olmayan kahramanını eşinden ve onun temsil ettiği dünyadan uzaklaştırır, boşanırlar. Daha sonra iş arkadaşlarından Mehmet adında birine âş̧ı olur ve eşini aldatır. Bu olay hayatındaki her şeyi sorgulamasına neden olur. Sadece eşinden değil, sosyal çevresinden ve işinden ayrılarak sıfırdan yeni bir hayata başlar. Zorlu bir mücadele ile başladığı iş hayatında istediği noktaya gelir. Bir yandan da erkekleri ve ilişkileri yakından analiz eder. Roman kahramanının hayatına giren erkek figürler farklı kişilik ve kültür düzeyindedir. Kahramanın flörtleri aslında kimliğini arayışının bir sembolüdür. Yani aşk ve güven duygusu arayışı ve bu çerçevede kadının kimliğini bulma yolculuğudur. Sonunda aslında ideal evlilik (veya ilişki) diye bir şeyin olmadığını anlar ve bir sonraki eserinin adını oluşturan “Aslında aşk da yok.” noktasına ulaşır.

\section{Mekân}

Kadının Adı Yok romanının mekânları orta sınıf bir ailenin yaşadığı evler (çocuklukta bahçeli sokağa açılan), apartman dairesi, iş yerleri, çok az olmakla birlikte sokaktır. Yaşanılan yer muhtemelen İstanbul'dur. Fakat roman kahramanının adından söz edilmediği gibi bir şehirden de doğrudan söz edilmez. Anlatılmak istenen herhangi bir kadının herhangi bir kentte yaşadıkları olduğu için buna gerek duyulmaz. Romanda kentli hayat tarzlarının sürdürüldüğü iç mekânlara ve orta veya büyük bir şehir olan dış mekânlara ait dikkat çeken tasvirlere de rastlanmaz. Okuyucunun dikkatine sunulan kadının somut ve soyut yaşantıları, sorgulamaları, problemleri ve bütünüyle duygu ve düşünceleri olduğu için perspektif bu alanlara yöneltilir. Kahramanın yaşadığı evler onun özgürlük yolculuğuna da eşlik eder. Bahçeli, müstakil baba evi geleneksel yaşantıyı, evlendikten sonra yaşadığı apartman daireleri küçük burjuva yaşantısını, son olarak da eşinden ayrıldıktan sonra kendi hayatını kurduğu basit, gösterişsiz, küçük evi roman kahramanının özgürlük dönemini sembolize eder. Kozasından çıktıktan sonra yaşadığı ev sadece onundur ve bu nedenle en mutlu olduğu özel alanıdır. Romanda bazı sembolik tekrarlara da rastlanır. Baba evindeki kafes, burjuva yaşantısının sembolü apartman daireleri, ona hareket özgürlüğü sağlayan otomobili, yeni hayatında taşındığı basit, gösterişsiz evi bunlara örnektir.

\section{Zaman}

Romanın zamanı belirtilmemekle birlikte olayların geçtiği dönemin romandaki biyografik izlerden yola çıkılarak 70’ler veya bilhassa 80'ler olduğu anlaşılmaktadır. Çünkü bahsi geçen hayat tarzı Türkiye'nin serbest piyasa ekonomisine girdiği, şirketleşme ve yeni bir tür zenginleşme türünün ortaya çıktığı bir dönemdir. Romanda kronolojik zaman bulunmakta, kahramanın çocukluktan yetişkinliğine kadar yaşadıkları çizgisel bir düzlemde verilmektedir. Yer yer çağrışımlar ve geriye dönüşlerle geçmiş yaşantılar anlatılmaktadır. Romanda zaman kavramı 
fonksiyonel olarak kullanılmış, kahramanın hesaplaşmaları, kişiliğini bulması ve özgürleşmesi belli bir zaman çizgisi üzerinde verilmiştir. Yalnız burada tarihsel bir zaman değil olgusal bir zaman fikri hâkimdir.

\section{Anlatıcı, Bakış Açısı ve Anlatım Tutumu}

Romanda olaylar kahraman anlatıcının dilinden anlatılmaktadır. Dolayısıyla romanın bakış açısı kahraman anlatıcı bakış açısıdır. Yer yer gözlemci bakış açısı kullanılmakla birlikte eserin kurgusundaki basitlik, biyografik özellikler ve çokça mesaj verme kaygısı romanda kahraman anlatıcının belirgin bir şekilde kullanılmasını gerektirmiştir Olayların tanığı da yaşayanı da anlatanı da aynı kişidir. Asena romanında işlediği konuya karşı ağırlıklı olarak eleştirel ve parodistik bir tutum benimsemiştir. Bununla birlikte Asena sıkça kullandığı iç monolog ve bilinç akımı teknikleriyle romanındaki figürlerin öznel gerçekliğini yansıtmıştır. Roman kahramanlarının düşünce ve sözlerini bunları yaşayan bir bilincin merceğinden yansıtarak “yaşanmakta olanı” ifade etmeye çalışmıştır.

\section{Dil ve Üslûp}

Romanın dili geneli itibariyle oldukça sade, konuşma diline yakındır. Cümleler kısa ve basittir. Romanda uzun edebî ifadeler yer almaz. Romanın yazılış amacı, bir gazete dili üslûbuyla her kesimden insana ulaşmak ve kolay okunmak olduğundan bu anlaşılabilen bir durumdur. Duygu Asena'nın gazeteci kimliğinden dolayı romanın genelinde bir gazetenin kadın sayfasında yer alabilen yazıların dil ve üslubunun birebir örneğini görmek mümkündür. Dikkat çeken tasvirlere, örneklemelere veya tanık göstermelere pek fazla yer verilmeyen romanda anlatımın tekdüzeliği dikkat çeker. Romanın genelindeki edebî açıdan iddiasız cümleler romanın bir edebiyat eseri olmamasının en açık delilidir. Bununla birlikte kadınların yer yer arkadaş çevresinde kendi aralarında kullandıkları anlatıma hareketlilik katan argo ifadelere de rastlanmaktadır. Romanın en sıkıntılı noktalarından estetik değerden yoksunluğuna rağmen anlatım bozukluğu ve cümle yanlışlarına rastlanmaması roman için artı bir değerdir.

\section{Romanda İşlenen Konu ve Temalar}

Kurgu, şahıs kadrosu, olaylar, dil ve üslup özellikleri açısından zayıf yönleri olan eserin asıl önemli tarafı güncelliğini devam ettiren işlediği konu ve temalardır. Bu yönleriyle dönemi açısından öncü bir eserdir. Yazar, eğitimli, modern ve geleneksel değerlerin bir arada yaşandığı bir kültürde orta sınıf bir kadınının karşılaştığı ve muhtemelen karşılaşacağı problemleri roman kahramanının gözünden, hayatı üzerinden bir dizi halinde sıralamıştır. Asıl vaka kadının kozasından çıkarak özgürleşmesi sürecinde yaşadıklarıdır. Bu yolculukta yaşadığı olaylar biyografisini tamamlayan durum ve yaşantılardır. Romanda işlenen temel tema “özgürlüktür”. Aşk, 
ezilmişlik, aldatma, temaları da romanda özgürlük temasının çerçevesinde işlenmiştir. Gelenekle Batılı hayat tarzı arasına sıkışmış orta sınıf şehirli Türk kadınının karşılaşabileceği veya şahit olabileceği türden kadın bedeni algısı, kız çocuğu olarak yetişmek, gençlik cinselliği, kürtaj, evlilik, kadının eğitim hakkı, iş hayatında ücret eşitsizliği romanda işlenen başlıca konulardır.

\section{Özgürlük}

Romanda baştan sona kendisiyle ve onu çevreleyen sosyal, kültürel sistemlerle savaşan kadının birey olma ve özgürleşme yolculuğu, bu yolcukta karşılaştığı problemler, bunları aşma yöntemleri ve nasıl savaşılacağı anlatılır. Kadının bedenine ve hayatına yönelik sınırlandırmalar, bu sınırlandırmaların neye hizmet ettiği, birey olabilmesinin yolları, tüm yasaklama ve sınırlandırmalarla hesaplaşılması özgürlüğün yolunu açacaktır. Ancak kendi sorumluluğunu kendisi alan kadın varoluşsal anlamda özgürdür ve tam manasıyla birey olabilir. Bu da ancak hesaplaşmayla eğitimle meslek sahibi olup ekonomik özerkliğini kazanmasıyla ve risk alabilmesiyle mümkündür. Bu açıdan "Kadınlar cesur olmalı ve kendine güvenmelidir.” mesajı romanda sürekli verilir.

Aşk

Aşk teması romanda özgürlük teması çerçevesinde ele alınmıştır. Zira kadın özgür olabildiği ölçüde aşkını yaşayabilir. Roman kahramanı ergenlik döneminde yaşadığı aşk duygusunun dışında erişkin bir kadın olunca yaşanan aşklara önce evlilik ilişkileri içinde yer verir, evlilik ve aşkın çatışmalarını sergiler. Roman kahramanı eşi tarafından aldatıldıktan sonra farklı kişilerle duygusal birliktelikler yaşar. Aşkın ne demek olduğunu da sık sık sorgular. Aşkın gelip geçiciliğini, insanın duygu ve düşüncelerinin değişebileceğini, önemli olanın samimiyetle o duygunun yaşanması olduğunu vurgular.

\section{Aldatma}

Romanda en belirgin temalardan biri aldatmadır. Aldatma temasının ilk örneği roman kahramanının lise yıllarında babasının annesini evlerine sürekli girip çıkan en yakın arkadaşı ile aldatması olayında işlenmektedir. Bu travmatik olay en yakınındaki erkek olan babasına olan güveninin derinlemesine sarsılmasına neden olur. Kahraman bu olayı annesine açıklayamaz. Çünkü annesi hayata karşı, pasif, edilgen ve yenik olmayı kabullenmiş pek çok Türk kadınından biridir. Şu ifadeler annenin çaresiz durumunu tasvir eder:

Annemin babamı sevdiğini sanmıyorum, ne konuşurlar, ne söyleşirler, ne birlikte içerler. Bunu anneme söylesem, iyice mutsuz olacak...ve gidemeyecek...gidecek bir yeri yok...çalışamayacak...çalışamaz... Gidebilseydi eğer, bunu ona söylerdim... Ama gidemeyecek ve söylemeyeceğim (Asena 2008: 42). 
Kadının yenikliğe ve pasif olmaya mecbur kalışının önemli nedenlerinden biri "gidecek yeri olmaması" problemidir. Bu problem çaresiz kalmış kadının karşılaştığı en sıkıntılı durumlardan biridir ve halen tam olarak çözülememiştir. Buna benzer bir durum romanda adı geçen Nilay adındaki genç kızın yaşadığı yasak aşk ilişkisinin babası tarafından fark edilmesi sonrasında dövülüp sokağa atılma hadisesidir ki olay, kadının gidecek yeri olmaması problemini çarpıcı bir şekilde dile getirmektedir.

Aldatma konusu bir de roman kahramanının bir eylem olarak karşımıza çıkmaktadır. Roman kahramanı eşinden duygusal olarak koptuğu ve çalışma hayatına başladığı dönemde iş arkadaşlarından Mehmet'le eşini aldatır. Daha önce kendisini iş seyahatlerinde aldattığını anladığı eşi Gürkan'dan göremediği ilgi, sevgi ve şefkati Mehmet’te bulmuştur. İşin tuhaf yönü ilişkilerinden her ikisinin eşlerinin haberlerinin olması ve aldatılmaya tepkisiz kalmalarıdır. Gürkan'ın bu aldatma ve aldatılma durumlarına karşı evliliğin her şeye rağmen sürdürülmesi gerektiğini tekrarlaması ve aşağılayıcı bir şekilde karısının gidecek yerinin olmamasını sürekli vurgulaması bu anlamsız evliliğin sonlanmasını hızlandırır. Mehmet'in karısının da ona sahip çıkması ve kendisini aldatan eşine aşırı sakin, tepkisiz ve kabullenici bir tavrı olması okuyucu tarafından çelişkili ve yadırgatıcı bir durum olarak görülmeye son derece müsaittir. Kaderine boyun eğen, kadınlık gururunun hiç olmadığı anlaşılan Mehmet'in karısı zayıf bir kurguya sahip olan romanda bir zayıf halka gibidir.

Roman kahramanının hayatına giren son erkeklerden biri romanda "Koltuk Değnekli Adam" olarak adlandırılan Orhan karakteridir. Mehmet ile ilişkisinin sonuna gelen roman kahramanımız onu Orhan'la aldatır. Orhan bir sokak çatışmasında belinden yaralandığı için koltuk değneklerine mahkûm hayatını sürdüren ve sürekli gizlenen bir illegal örgüt üyesidir. Karanlık işlerin içindedir. Hatta bir keresinde roman kahramanını kurye olarak kullanmıştır. Roman kahramanı için hayatındaki bir eksiği tamamlamaktadır. Orhan'la her konuda rahatça iletişim kurabilmektedir. Toplumsal meselelerden, kadın-erkek ilişkilerinden, kültürel konulardan saatlerce konuşabilmektedir. Bu onun önceki ilişkilerinde görmediği bir durumdur. Mehmet de bu duyguları tatmamıştır. İz bırakan, farklı bir boyutta, kısa bir ilişskisi olan Koltuk Değnekli Adam “Orhan” bir bilinmeze doğru gitmiş, yok olmuştur.

Romanda kahramanın hayatına giren son adam da Aydın'dır. Aydın aradığı her şeye sahip gibi biridir. Onula çok mutlu olmuştur. Ancak onun iş dolayısıyla yurt dışına gitmesi gerekmektedir. Onu da götürmek ister. Ancak büyük mücadele ile kurduğu düzenini değiştirmek istemez. Aydın'ın parasıyla onun düzeni içinde yaşamayı reddeder. Özgür kadın birlikte olduğu erkeğinin parasıyla onun düzeni içinde yaşamamalıdır. 
Romanda -en çok kendisinin içinde bulunduğu- bütün aldatmalara ve yalanlara karşı duruş sergileyerek özgür kadın olmanın mücadelesini veren roman kahramanın kendisinin de önce eşini daha sonra da bazı flörtlerini aldatması okuyucunun kafasını karıştıran bir çelişki gibi görülebilir. Romanda vurgulanan düşünce yapılmış çok büyük bir hata da olsa arkasında durmanın ve dürüstlüğün erdemidir. Anlatılmak istenen durum nikâhlı veya nikâhsız sevgi ve saygının olmadığı cinselliğin bir eleştirisidir. Asıl özgürlük bu yapay içtenliksiz -bir yerde çıkara dayanan- ilişkinin dürüstçe sonlandırılmasıdır.

\section{Kadın Bedeni Algısı}

Romanda işlenen konulardan biri de kadının kendi bedeni ve cinselliğine toplumsal kodlarla bakmasının ve bu şekilde algılamasının dayatılmasıdır. Yani kadının bedeni bir kadın olduğu için değil de anne olacağı için vardır. Cinselliği de anne olmak ve erkeğinin kadını olmak noktasında var olmalıdır. Romanın başlarında roman kahramanı henüz küçük bir kızken bedeni annesi tarafından kendisine o şekilde tanıtılır. Toplumsal kodlara göre flörtlerinde ve evliliğinde erkekleri cinsel yönden memnun etmek ondan beklenen ilk şeydir. Kadınların duygusal beklentileri görmezden gelinir. Kadın bedeni ve cinselliği erkek egemen sistemin işleyişinde yalnızca bir vasıtadır. Üremenin ve erkekleri memnun etmenin yegâne aracıdır. Çeşitli sosyal ve kültürel dayatmalarla korkutularak kontrol altına alınması gereken "tehlikeli” bir şeydir. Kadının duygularınınsa pek bir önemi yoktur. İște Duygu Asena romanında bu problemi vurgulamak istemiş, kadının özgürlük yolculuğun bedenine ve cinselliğine sahip çıkmanın önemini anlatmak istemiştir. $\mathrm{Bu}$ nedenle kitap kadınların bedenleriyle yüzleşmelerini işlemesi bakımından Türk edebiyatı için cesur bir adımdır.

\section{Ataerkil Ailede Kız Çocuğu Olarak Yetişmek}

Çocukluktan ergenliğe geçiş, ergenliğin ruhsal ve fiziksel değişimleri, ilk aşklar, genç kızın annesi ve babası üzerinden kadın erkek ilişkilerini sorgulayışı romanın ilk bölümlerinde birbiri ardına işlenen konular arasındadır. Babası Türk aile babası tipini fazlaca yansıtan, egemen, güçlü, karısı ve çocukları üzerine hâkimiyetini kurmuş bir babadır. Bütün kaygısı kızlarını toplumun belirlediği ölçülere göre yetiştirmektir. Bu nedenle kızlarının henüz kadın erkek ayrımını fark edemeyecek yaşlardan itibaren erkeklerle oynamasını engeller. Erkeklerle oynanan en masum oyunları bile karşıt cins ilişkisi olarak yorumlar. Kızlarına erkeklerden uzakta durulması gereken varlıklar olduğu öğretilir. Bu da yine korkutarak ve sindirerek gerçekleşir. Kızlarını erkeklerden uzak tutmayı temel mesele olarak gören baba romanda etkili bir biçimde teşhir edilmiştir. Erkek egemen toplumun adım adım ailede nasıl inşa edildiği anlatılmıştır (DAS, 48). 
Engellemeler kızların ergenlik çağında hat safhaya ulaşmıştır. Babanın tüm müdahalelerine rağmen kızlarının zaman zaman flörtleri olur. Anne ise pasif, içe dönük, ekonomik özgürlüğü olmayan, babaya bağımlı bir ev hanımıdır. "Otoriteye boyun eğen” ve "öğrenilmiş çaresizlik içinde sesini çıkaramayan” klasik Türk kadını tipidir. Ancak kızları için çok endişelenmektedir. Zaman zaman kızlarını baba baskısından korumak için babaya karşı diklense de siner ve çekilir. Erkek ne yapsa haklıdır ve ne yapsa sorgulanamaz anlayışı ile ezikliğini bir ömür boyu yaşamıştır. Roman kahramanının ilk fark ettiği şeylerden biri annesinin bu denli ezik ve pasif davranmasının en önemli sebebinin parasızlık olduğudur. Ayrıca gücün önemini kavramış, bunun ancak kadınların erkeklerin yapabildikleri işleri yaparak ve cesaretlerini göstererek mümkün olacağını keşfetmiştir.

\section{Gençlik Cinselliği ve Bunun Yarattığı Sıkıntılar}

Okul çevresi ve oradaki kız erkek ilişkileri romanın ilk bölümlerinde irdelenen konular arasındadır. "Erkeklerin tehlikeli olduğu ve bir genç kızın mutlaka bedenini sakındırması gerekliliği”nin sürekli vurgulandığı aile eğitiminde kızlar ve erkekler; normal, sağlıklı bir kız erkek arkadaşlık ilişkisi geliştirememekte, kolayca ilişkileri cinselliğe dönüşebilmektedir. Kitabın bu bölümünde genç bireylerin cinselliklerini keşfetmeleri ve akabinde yaşanan ve sadece kadının suçlandığı ve mağdur olduğu durumlar anlatılır. Bilhassa okul arkadaşlarından Fügen'in gençlik heveslerine yenilerek hamile kalışı, çocuğunu aldırırken yaşadığı süreç, erkek arkadaşı tarafından da yalnız bırakılışı, sonrasında yaşadığı ötekileştirme ve diğer travmatik olaylar bir genç kızın oldukça gerçekçi gözlem ve tespitleri ile anlatılır.

\section{Evlilik}

Evlilik romanda işlenen temel konulardan biridir. Kendi anne babasından başlayarak arkadaşlarının sonra da kı kardeşinin evliliğine şahit olması yazarın evlilik kavramını sorgulamasına sebep olur. Kendisi de bazen kısa süren bazen evlilik eşiğine gelecek nitelikte birlikteliklerin ardından döneminin standart evlilik anlayışı açısından iyi sayılabilecek bir evlilik yapmıştır. İlk zamanlar ideal bir çerçevede karı-koca hayatının olduğu ve kahramanın ev hanımı olarak görevlerini eksiksiz yerine getirdiği evlilikleri zamanla rutinin yaşandığı seremonilere dönüşür. Kariyer sahibi bir eş, ekonomik rahatlığın, üst düzey sosyal ilişkilerin olduğu bu evlilikte eksik olan şey tutku ve kadının özgürlüğüdür. Ancak çevresinde üst sosyo-ekonomik tabakadaki kadınların durumunu gözlemleyen yazar güçlü erkeklerin yanında statü elde etmeye çalışan kadınlar karşısında şu sözleri sarf etmektedir:

O kalburüstü insanların bulunduğu yemeklerde kendimi gerçekten garip hissediyorum. Kadınlar koskoca kürklerinin içinde, en büyük pırlantaları ve en kalın altınlarıyla, markaları fışkırdığı 
giysileri, en son moda, yapılı ve mutlaka boyalı saçlarıyla; o kadınlarla konuşacak hiçbir şeyim yok. Kocası patron olan kadın, en çok ilgiyi topluyor, en fazla saygı ona gösteriliyor....

Hep birbirimize tanıştırılıyoruz...”Efendim, Tü-Pa-Ka AŞ’den Abdullah Günver Bey’in eşleri. “Oooo, memnun oldum efendim, ben de Sam-Kor AŞ'den Hüseyin Topal Bey'in eşiyim, nasılsınız?"' Ben mi, benim adım şu, soyadım da şu, ben filanca şirketin, filanca servisinin şefiyim...Memnun oldum, eşiniz kim...

...Kadınlar genellikle oturuyor. Evlerdeki grup grup koltuklar üzerinde grup grup kadınlar oturuyor, ellerinde içki bardakları... Hiç gürültü yapmadan, kocalarının ne kadar yorulduğundan bahsediyorlar, ne kadar şık oldukları hakkında birbirlerine iltifat ediyorlar, Almanya bir köymüş, İngiltere kendi stilinden vazgeçememiş bir türlü, ama ille de Paris, ille de Paris'miş, ya İtalya...

Sonra da çocuklar konuşuluyor, genellikle hangi okulda oldukları, hangi ülkede oldukları, belli ki hiçbirinin çocuklarıyla ilgili eğitimsel sorunları yok. Arada bir yemek tarifi yapan bile çıkıyor. Ne kadar enerji harcıyorum, ne kadar çok düşünüyorum içimden, onların konuşmalarına katılmak için söyleyecek tek bir söz bulamıyorum ( Asena, 2008: 96-97).

Ancak gücün kadının cesareti ve ekonomik özgürlükle kazanabileceğini anlayan, sevdiği ve sevildiğine inandığ birkaç ilişkisi olan roman kahramanı bir daha evlenmemiş, evliliğe ve erkeklere olan inancını da kaybetmiştir.

İnsan ilişkileri üzerine çalışmalarıyla tanınan Zygmunt Bauman Parçalanmış Hayat adlı eserinde birliktelik biçimlerini "yanında olma", "ile olma" ve "için olma" şeklinde tasnif etmiştir. "Yanında olma; bazen kasıtlı bazen tesadüfi birliktelikleri (sokakta, işyerinde vs.) anlatır ; "ile olmak" ise kişiliğinde eksiklikleri olan benliklerin buluşmasıdır. "İçin olmak"ta ise faydalı, doyurucu ve zevkli bir hayat sürme söz konusudur. Partnerlerin birbirleriyle "ile olmak”tan başka bir türlü davranmaları gerekmektedir. İdeal olan birliktelik “için olmak” birlikteliğidir. ( Bauman, 2001: 71-76) Bu tespitten yola çıkarak kahramanımız "ile olmak" şeklindeki ilişki çeşitlerinin kaosunda kaybolmuş ve ilişkilere dair inancını kaybetmiştir.

Evlilik ve eş seçimi ile ilgili olarak kız kardeşi Nilay’ın evliliği de romanda geniş bir yer tutmuştur. Nilay, ablasının aksine kendisine dayatılanlara karşı çıkmayan, kaderine boyun eğen bir karakterdir. Entelektüel yönleri olan bir eşe sahip olduğu halde yine de kısıtlamalar ve riyakârlıklarla karşılaşmıştır. Evlendiği kişi bir tiyatrocudur. Kültürlü bir insan olmasına rağmen karısını sosyal çevresinden uzak tutar, ona evin dışında bir hayat hakkı tanımaz. Kültürlü görünen ama iç dünyasında klasik maço tavırlarını yaşayan bir karakter olarak romanda yerini alır. Çocuk sahibi olduktan sonra kendinden ve ideallerinden adım adım uzaklaşmış bir genç kadının yaşadığı üzüntü verici hayat, evliliğin asıl yükünün kadın tarafından yüklenildiğini ortaya koymaktadır. Nilay'ın eşi ile ilgili şu sözleri dikkat çekicidir: 
...Birden kafamda bir nokta aydınlanıyor, ta yıllar önce, tiyatrocunun gözümüze sevimli geldiği dönemde, bir içki sofrasında söylediği sözü anımsıyorum: "Takacaksın kadına iki çocuk, oturtacaksın evde, ondan sonra, sen, gel keyfim gel...” Biz bu sözü şaka sanıp gülmüştük...

Tiyatrocu içki kokuları sala sala odadan çıkıyor... Beni küçük düşürmek için birden bire hiç duymadığım edebiyatçıların, tiyatro yazarlarının adlarını ve yapıtlarını sıralamaya başlıyor..."Ya, küçük hanım, duymuş muydun bunları" diyor...

Senin entelektüelliğin batsın, yamalı herif, yamaların sökülünce görülüyor içindeki yırtık" diyorum; ama tabii içimden, bundan sonra kardeşimden hiç söz etmeyeceğim (Asena,2008: 56-57).

Romanda vurgulanan noktalardan biri de "bekâr, boşanmış" kadın algısıdır. Bilhassa bazı kadınlar tarafından evli olmayan kadın potansiyel bir tehdit gibi görülmekte, zaman zaman hemcinslerine yönelik dışlama ve ötekileştirme davranışları sergileyebilmektedirler.

Evli arkadaşlarımın çoğu beni gece toplantılarına çağırmıyorlar, tecrit edildim. Cumartesi günleri kadın kadına toplanıyoruz ama gece davetlerinde ben yokum. Bir kocam, bir sahibim olmadığı için göze batıyorum, istenmiyorum. Arada bir iş davetiyeleri geliyor ama hep eşinizle birlikte...(Asena, 2008:182).

\section{Romana Göre Türk Toplumunda Kadın Algısı}

Romanda sorgulanan noktalardan biri Türk kadını algısı ve toplumun kadından beklentileridir. Roman kahramanı bu sorgulamayı çocukluğundan beri toplumun normlarına uygun "kız çocuğu (veya genç kız) olma" noktasında yapmış, evlendikten sonra da kendisini kadın olarak sorgulamaya başlamıştır. Hem bir birey olarak hem de toplum normlarına göre kadın olarak çatışmalarını evliliğinin başlarında yaşamıştır. Roman kahramanı çocuk sahibi olma konusu üzerinden çatışmalarını şu cümlelerle çarpıcı bir şekilde ifade etmektedir:

.... Evleneceksin hemen bir çocuğun olacak, mutlu kadın olacaksın...Mutlu kadın gibi yapacaksın. Evlenir evlenmez, o adamın ilerde bir yabancı olabileceğini bilmeden, o adamın bir gün gelip, o sevdiğin, tanıdığın adam olmayabileceğini bilmeden, bir gün ondan ayrılabileceğini düşünmeden bir çocuk yapmak gerektiğini sanıyordum. Bize öyle öğretmişlerdi çünkü. Kadının en kutsal ve tek görevi analıktır. Ancak ana olamayan kadınlar, eksiklerini telafi etmek için kendilerini yüceltmek isteyip iş hayatına atılır, erkeklerle aşık atmaya kalkarlar (Asena,2008: 113).

\section{Kadının Eğitim Hakkı ve İş Hayatı}

Romanda ele alınan konulardan biri de kadının ekonomik özgürlüğünü sağlayacak ve onun "birey olma” yolunda kimliğini güçlendirecek “eğitim”, bilhassa "meslek eğitimi”" hakkıdır. İlk ve orta öğretimde bu mesele aşılmış, iş üniversiteye gelince baba engeliyle karşılaşılmıştır. Babasının engellemeleri yine birtakım korkulara ve kalıplaşmış ataerkil düzen anlayışına dayanır. Zira babanın istememesine rağmen gizlice üniversite sınavına girmiş, kazanmış, babasına bir emrivaki 
ile üniversiteye gideceğini söylemiş ve eğitimini almıştır. Aldığı eğitim evliliğinde aldığı darbeleri yenmesinde, ayakta kalmasını sağlayacak ekonomik ve sosyal özgürlüğünü sağlamasında işe yaramıştır.

Geçmişten bugüne kadının ekonomik hayatında en çok karşılaştığı problemlerden biri ücret eşitsizliğidir. Aynı eğitime, çalışma düzenine (bazen erkeklerden daha fazla olmak üzere) sahip olasına rağmen bilhassa özel sektörde ücret eşitsizliği ile karşı karşıya gelebilmektedir. Bu problem ne yazık ki kanıksanmış bir durum olarak da süregelmektedir. Ayrıca kadının işe alınması ve iş yerinde statü atlaması, bazı erkekler tarafından doğal bir durum olarak değil, kadınlığını kullandığg şüphesiyle şaibeli bir durummuş gibi karşılanması romanda işlenen sorunlar arasındadır.

\section{Sonuç}

Son dönem Türk romanının çok okunmuş, tartılmış ve çeşitli dillere çevrilmiş romanlarından biri Duygu Asena'nın Kadının Adı Yok adlı romanıdır. Duygu Asena'nın adıyla bütünleşen eser; kadın meselesini geniş bir toplumsal platforma taşımış, Duygu Asena’yı Türk okuyucusuna iddialı bir isimle tanıtmıştır. Asena'nın yumuşatarak ve sadeleştirerek feminizmin söylemlerini geniş kadın kitlelerine sunduğu Kadının Adı Yok dönemi için öncü bir eserdir. Kitap baştan sona bir kadınlık hali öyküsüdür. Türkiye'de eğitimli meslek sahibi kadınların dahi hak ve özgürlüklerini kullanmakta nasıl sorunlar yaşadığı, toplumun ve yerleşik değerlerin karşısında kendini savunan kadının nasıl sistem tarafından dışlandığı romanda açık seçik anlatılmıştır. Roman kadının hem bireysel hem de toplumsal sorunlarını tespit etme hem de bu sorunlarla nasıl başa çıkılacağını göstermesi açısından bir özgürleşme hikâyesidir. Aşkı yücelten, kadınlara onurlu ve eşit bir hayatın nasıl yaşanacağını, inandığı gibi yaşamayı ve bundan suçluluk duymamayı öğütleyen eser, Şirin Tekeli'nin deyimiyle bir kadın manifestosudur. Bir başka ifadeyle toplumun ikiyüzlülüğüne bir karşı çıkış olarak değerlendirilmesi gereken roman, topluma ve kadına yöneltilen tabularla nasıl hesaplaşılacağını anlatmakta, kadınların kendi hayatlarına ve kadınlıklarına sahip çıkmaları öğütlenmektedir. Eser bütünüyle kadının sosyo-ekonomik ve psikolojik olarak güçlü olmasının özgürlüğüne açılan tek yol olduğunu vurgulamaktadır. Kadının kabul edilebilir sınırlar içinde yaşaması, evine ve kocasına hizmet etmesini öğütleyen sisteme ciddi bir cevap niteliğindedir. Kadının $A d \imath$ Yok edebî yönü zayıf bir eserdir. Yazarının da çeşitli vesilelerle ifade ettiği gibi yalnızca mesaj vermek, kadın sorununu toplumsal düzleme taşımak için yazılmıştır. Gerçekten de eser ve yazarı amacına ulaşmış, roman yayımlandığı tarihten itibaren kadının çığlığını güçlü bir şekilde duyurmuştur.

\section{Kaynakça}

Asena, D. (2008). Kadının Adı Yok, İstanbul: Doğan Kitap. 
Asena, D. (2016). Orada Kadınlar Var mı?, Derleyen: Şadan Maraş Öymen, İstanbul: Doğan Kitap.

Aytaç, G. (2012). Çağdaş Türk Romanı Üzerine Incelemeler. Ankara: Doğu Batı Yayınları.

Bauman, Z. (2001) .Parçalanmış Hayat, İstanbul: Ayrıntı Yayınları.

DAS (Duygu Asena'ya Sayg1) (2007). Gücünüzü Bilin, Haz. Reyhan Yıldız, İstanbul: Erko Yayıncilı.

Özturkmen, A. (2000). "A Short History of Kadınca Magazine and Its Feminism," Deconstructing Images of "The Turkish Woman," ed. Zehra Arat. New York: St. Martin's Press, s.275-293.

Tekeli, Ş. (1983). "Cumhuriyet Dönemi Seçimler", Cumhuriyet Dönemi Türkiye Ansiklopedisi, 4. Cilt, İletişim Yayınları, İstanbul 1983.

Işık, E. (2013). Türkiye Ünlüleri Ansiklopedisi, Ünlü Kadınlar, Ankara: Elvan Yayınları.

İplikçi, M. (2007). “Çığır Açan Kadının Ardından...”, Duygu Asena’ya Saygı, Gücünüzü Bilin, Haz. Reyhan Yıldız, İstanbul: Erko Yayıncılık.

Kadının Ad1 Yok - Duygu Asena (2010, Eylül 29). Erişim Linki: https://ww.dailymotion.com/ Erişim Tarihi:26.09.2010.

Külahlığlu İslam, A. (2011).”Cumhuriyet Dönemi Türk Hikâyesi”, Yeni Türk Edebiyatı El Kitabı, Editör: Ramazan Korkmaz, Ankara: Grafiker Yayınları, 370-373. 